\title{
Outcome of Stereotactic Radiotherapy for Patients with Uncontrolled Acromegaly
}

\author{
Syed Ali Imran, Ian G. Fleetwood, Colleen M. O'Connell, Thomas P. Ransom, \\ Liam A. Mulroy, Ehud Ur, David B. Clarke
}

\begin{abstract}
Objective: Linear accelerator based stereotactic radiation therapy (SRT) has been used for the treatment of pituitary tumours; however, little is known concerning the use of this modality for the treatment of patients with acromegaly. We have prospectively studied the short-term outcome of SRT in 12 acromegaly patients who failed to achieve biochemical remission despite surgery and/or pharmacologic therapy. Methods: We identified all patients who had biochemically uncontrolled acromegaly and were treated with SRT between April 2003 and December 2006. All patients were followed prospectively based on a pre-defined protocol that included Goldman visual field examination, MRI of the sella, and pituitary hormone testing at 3, 6, 12 months, and then yearly. Results: A total of 12 patients with acromegaly were treated with SRT. There were 9 females and the median age of the group was 50 years. The median follow-up was 28.5 months during which time the mean tumor volume decreased by $40 \%$, the median GH fell from $4.1 \mu \mathrm{g} / \mathrm{L}$ to $1.3 \mu \mathrm{g} / \mathrm{L}(\mathrm{p}=0.003$ ) and the median IGF-1 dropped more than half from $545.5 \mu \mathrm{g} / \mathrm{L}$ to $260.5 \mu \mathrm{g} / \mathrm{L}$ (p=0.002). Four patients achieved normal, while an additional 2 achieved near-normal, IGF-1 levels. One patient was able to discontinue and two were able to reduce their acromegaly medications while maintaining a normal IGF-1. A new pituitary hormonal deficit was found at 24 months in one patient who developed hypoadrenalism requiring corticosteroid replacement. Conclusion: Based on our early experience, we believe that SRT should be considered in treating patients with uncontrolled acromegaly.
\end{abstract}

RÉSUMÉ: Réponse thérapeutique à la radiothérapie stéréotaxique chez les patients atteints d'acromégalie rebelle. Objectif : La radiothérapie stéréotaxique (RTS) par accélérateur linéaire est utilisée pour le traitement des tumeurs hypophysaires. Cependant, on connaît peu de choses sur l'utilisation de ce mode de traitement chez les patients atteints d'acromégalie. Nous avons étudié de façon prospective le résultat thérapeutique à court terme de la RTS chez 12 patients atteints d'acromégalie, chez qui la chirurgie et/ou la pharmacothérapie n'a pas provoqué de rémission biochimique. Méthodes : Nous avons identifié tous les patients dont l'acromégalie n'était pas maîtrisée au point de vue biochimique, qui ont été traités par RTS entre avril 2003 et décembre 2006. Tous les patients ont été suivis de façon prospective selon un protocole prédéterminé comportant un examen des champs visuels (Goldman), une IRM de la selle turcique et un bilan hormonal hypophysaire après 3, 6, et 12 mois, puis annuellement. Résultats : Douze patients atteints d'acromégalie, dont 9 femmes, ont été traités par RTS. L'âge médian des patients était de 50 ans et le suivi médian était de 28,5 mois. Le volume moyen de la tumeur a diminué de 40\%, le taux médian de somatotrophine est passé de 4,1 $\mu \mathrm{g} / \mathrm{L}$ à $1,3 \mu \mathrm{g} / \mathrm{L}(\mathrm{p}=0,003)$ et le taux médian d'IGF-1 a chuté de plus de la moitié, passant de $545,5 \mu \mathrm{g} / \mathrm{L}$ à $260,5 \mu \mathrm{g} / \mathrm{L}(\mathrm{p}=0,002)$. Le taux d'IGF-1 est redevenu normal chez quatre patients et quasi normal chez deux autres. Un patient a pu cesser de prendre ses médicaments pour traiter l'acromégalie et deux autres ont pu en réduire la posologie tout en maintenant un IGF-1 normal. Un nouveau déficit hormonal hypophysaire a été constaté chez un patient après 24 mois de suivi, soit un hypoadrénalisme nécessitant un remplacement par des corticostéroïdes. Conclusion : Suite à ces premières observations, nous croyons que la RTS devrait être envisagée chez les patients qui présentent une acromégalie rebelle.

Can. J. Neurol. Sci. 2009; 36: 468-474

Radiation remains an effective alternative to medical therapy in surgically incurable cases of acromegaly. The aims of treatment are to alleviate morbidity and undue mortality by controlling tumour mass and by normalizing serum growth hormone $(\mathrm{GH})$ and insulin like growth factor (IGF-1) levels. Since pituitary radiation was first reported almost a century ago ${ }^{1}$, the technique has transformed dramatically. In recent years, improvements in technology and computer software have led to the development of more precise delivery of radiation, such that stereotactic radiosurgery (SRS) and stereotactic radiation therapy (SRT) have replaced conventional external beam radiation techniques. Stereotactic radiation therapy delivers a highly conformal radiation dose to a definable lesion, such as a pituitary adenoma, with relative sparing of radiation effect on adjacent normal tissues. Whilst the outcomes of both conventional radiotherapy and SRS techniques in patients with GH producing adenomas have been well described in the literature ${ }^{2-4}$, the

From the Halifax Neuropituitary Program and Departments of Surgery (Neurosurgery; IGF, DBC), Medicine (Endocrinology; SAI, TPR, EU), Perinatal Epidemiology Research Unit (CMO) and Radiation Oncology (LAM), Dalhousie University, Halifax, Nova Scotia, Canada.

Received January 9, 2009. Final Revisions Submitted March 27, 2009. Correspondence to: David B. Clarke, Halifax Neuropituitary Program, Division of Neurosurgery, 1796 Summer Street, Room 3807, Halifax, Nova Scotia, B3A 3A7, Canada. 


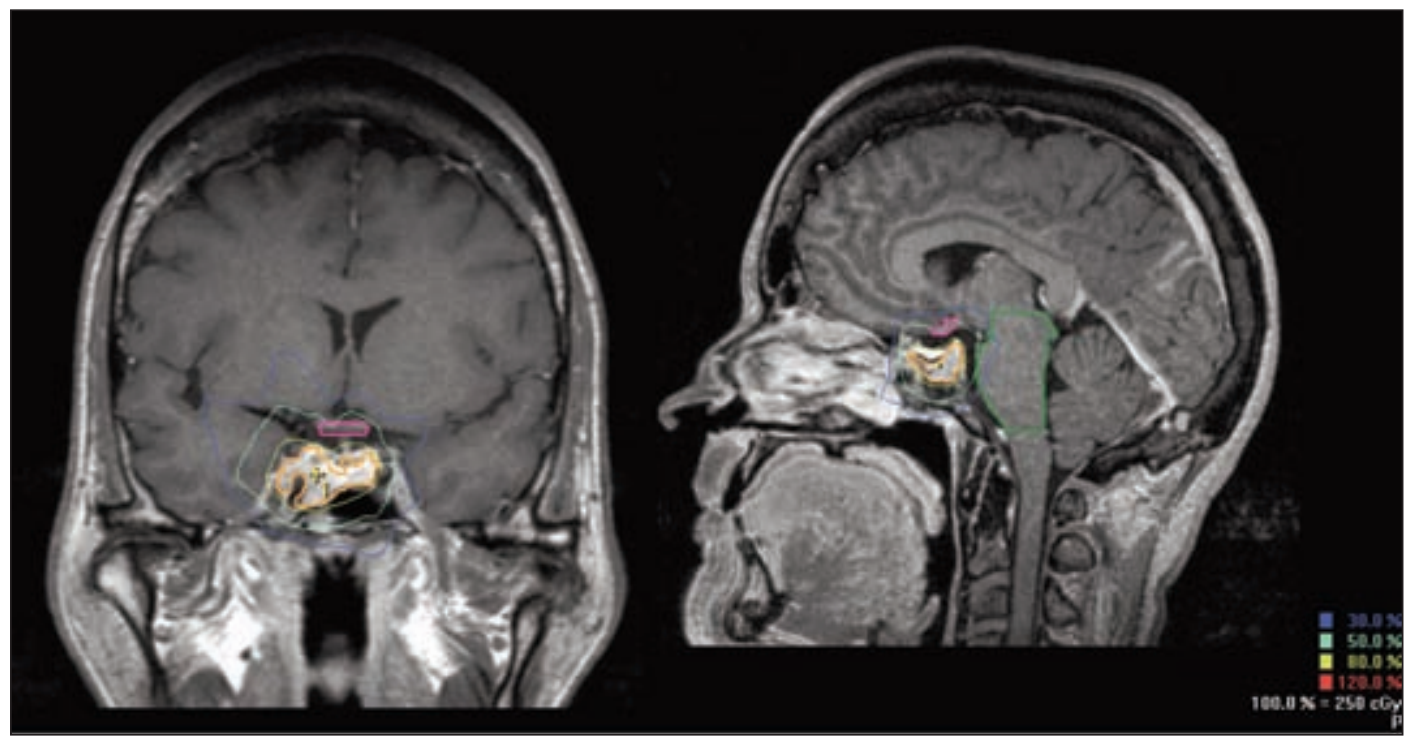

Figure 1: Coronal and sagittal MRI planning (images from Patient \#1). The adenoma and adjacent dose-limiting critical structures (including the optic chiasm and brainstem, outlined here) were contoured. A dose of 5,000 cGy in 25 fractions was prescribed to the tumour margin at the $80 \%$ isodose line. Colour version of this figure is available on-line. (www.cjns.org)

effectiveness of SRT in specifically treating this disease has not been widely reported. We have prospectively gathered data on 12 patients treated with SRT for uncontrolled acromegaly and report on the effectiveness of this treatment in terms of biochemical and radiological responses.

\section{SubJects AND Methods}

\section{Subjects}

The study protocol was approved by the Capital Health Research Ethics Board. All patient data for those treated with SRT were collected prospectively and entered into the Halifax Neuropituitary Program's database. From this database, we identified all patients who were treated for surgically incurable and medically refractory acromegaly by SRT, and who had a minimum follow-up of six months, for inclusion in the study. The diagnosis of acromegaly was based on the presence of typical clinical features of excessive GH production, elevated serum IGF-1 levels compared with age and gender matched normal values, and non-suppression of $\mathrm{GH}$ to $<1 \mu \mathrm{g} / \mathrm{L}$ after an oral glucose tolerance test. The primary indication for SRT in all patients was the lack of biochemical control that was confirmed by demonstrating persistent elevation of age and sex adjusted IGF-1, despite previous surgery and/or medical therapy. Ten patients had previously undergone transsphenoidal pituitary surgery for GH producing macroadenomas and still had residual pituitary adenomatous tissue, while the remaining two patients had received pharmacologic treatment only. All patients underwent a neurosurgical evaluation and were felt not to be surgical candidates, because either surgery was not acceptable by the patient or it was felt that surgery would have a low probability of cure.

\section{SRT Treatment}

All patients were treated using the BrainLAB micro-multileaf collimator fitted on a Varian $600 \mathrm{C}$ linear accelerator. Planning was carried out using BrainSCAN 5.2 treatment planning software (@1989/2002 by BrainLAB AG) and later using BrainSCAN 5.31 (@1989/2004 by BrainLAB AG). Prior to treatment, patients were fitted with a customized aquaplast mask for the BrainLAB re-locatable head frame, which allowed stereotactic imaging and provided immobilization of the head. Previous work from our centre has documented precision of isocentre targeting during fractionated treatment using this apparatus $^{5}$. A stereotactic non-contrast planning CT scan was carried out with axial slices at $1 \mathrm{~mm}$ intervals obtained at the level of the pituitary adenoma. The rest of the brain and skull was scanned with $3 \mathrm{~mm}$ axial slices. Each patient had a gadolinium enhanced MRI scan (Seimens 1.5T: 3D MP RAGE $1.25 \mathrm{~mm}$ sagittal slices and T1W $3.0 \mathrm{~mm}$ slices in axial and coronal planes post-gadolinium) which was fused with the planning CT scan in an automated fashion.

The adenoma, as well as adjacent dose-limiting critical structures such as the optic nerves, chiasm, eyes and brainstem, were contoured (Figure 1). No margin was added to the adenoma, such that the planning target volume was equal to the clinical target volume. Individual treatment plans were generated, typically using 8-15 non-coplanar static conformal 6 MV photon beams. Radiation dose was prescribed to the tumour margin at the $80 \%$ isodose line in all patients. The prescription dose was 5,000 cGy in 25 fractions in 11 patients; in one patient where a small residual adenoma was located far from the optic chiasm, 2,500 cGy were delivered in five fractions. Medical therapy was not stopped during SRT. Patients were seen weekly during SRT by their attending radiation oncologist. 
Table 1: Patient information

\begin{tabular}{c|c|c|c}
\hline $\begin{array}{c}\text { Patient } \\
\#\end{array}$ & Gender & $\begin{array}{c}\text { Age } \\
\text { (yr) }\end{array}$ & $\begin{array}{c}\text { Previous treatment (year } \\
\text { treatment given/started) }\end{array}$ \\
\hline 1 & $\mathrm{~F}$ & 53 & $\mathrm{TSS}(2003), \mathrm{SA}(2002)$ \\
\hline 2 & $\mathrm{~F}$ & 42 & $\mathrm{TSS}(1999), \mathrm{DA}(2002)$ \\
\hline 3 & $\mathrm{M}$ & 39 & $\mathrm{TSS}(2001), \mathrm{DA}(2002)$ \\
\hline 4 & $\mathrm{~F}$ & 62 & $\mathrm{TSS}(1998), \mathrm{SA}(2002)$ \\
\hline 5 & $\mathrm{~F}$ & 52 & $\mathrm{TSS}(2001), \mathrm{DA}(2001), \mathrm{SA}(2005)$ \\
\hline 6 & $\mathrm{~F}$ & 49 & $\mathrm{TSS}(2001), \mathrm{SA}(2001)$ \\
\hline 7 & $\mathrm{~F}$ & 40 & $\mathrm{SA}(2002), \mathrm{Peg}(2005)$ \\
\hline 8 & $\mathrm{~F}$ & 32 & $\mathrm{SA}(2002), \mathrm{TSS}(2003)$ \\
\hline 9 & $\mathrm{M}$ & 52 & $\mathrm{TSS}(2005), \mathrm{SA}(2005)$ \\
\hline 10 & $\mathrm{M}$ & 59 & $\mathrm{DA}(2002), \mathrm{SA}(2002)$ \\
\hline 11 & $\mathrm{~F}$ & 51 & TSS (2005), SA (2005) \\
\hline 12 & $\mathrm{~F}$ & 54 & TSS (2004), SA (2004) \\
\hline
\end{tabular}

$\mathrm{TSS}=$ transsphenoidal surgery; $\mathrm{SA}=$ somatostatin analogue; $\mathrm{DA}=$ dopamine agonist; Peg = pegvisomant

\section{Follow-Up Protocol}

A radiation oncologist contacted all patients by phone one month after treatment was completed to monitor for acute and early subacute toxicity. Patients were then seen in a multidisciplinary clinic by the neurosurgeon, endocrinologist and radiation oncologist three to six months after the SRT treatment. Thereafter, they were followed every six months for two years and then annually. At each of these clinic visits, patients underwent a careful clinical evaluation, Goldmann visual field testing (all performed at the same centre and interpreted by a single ophthalmologist), MRI of sella (with and without gadolinium enhancement), and $0800 \mathrm{~h}$ blood sample testing that included serum IGF-1, GH, cortisol, luteinizing hormone $(\mathrm{LH})$, follicle stimulating hormone (FSH), thyroid stimulating hormone (TSH), free thyroxine (T4), total testosterone, estradiol, prolactin, and electrolytes. The pharmacologic therapy was gradually reduced or withdrawn in patients who achieved and maintained normal IGF-1. Biochemical remission was defined as achieving both normal IGF-1 as well as $\mathrm{GH}<2.5 \mu \mathrm{g} / \mathrm{L}$, with or without pharmacologic therapy. For those patients who were unable to maintain normal IGF-1, the minimum effective dose of pharmacologic therapy was maintained. Assays for cortisol, prolactin, FSH, LH, TSH and T4 were performed routinely by immunoassays with chemiluminescent detection using an ADVIA Centaur system (Bayer HealthCare, Tarrytown, NY). Growth hormone and IGF1 were similarly measured using the Immulite 2000 system (Diagnostics Products Corporation, Los Angeles, CA).

\section{Tumour Volume}

The pituitary adenoma volumes were calculated by the treatment planning software prior to SRT treatment according to the contoured planning target volume. Subsequently, the most recent follow-up MRI scan on each patient was imported into the treatment planning software and the residual tumour was again contoured such that comparative analysis could be performed.

\section{Statistical analysis}

The baseline pre-SRT treatment serum levels of hormones $(\mu \mathrm{g} / \mathrm{L})$ were compared with levels taken at subsequent patient follow-up visits. Baseline pre-SRT treatment tumour volumes (cc) were compared with measures taken at the last patient follow-up evaluation. Results of these nonparametric median values were compared using the Wilcoxon Signed Ranks Test (SPSS, v14).

\section{RESULTS}

Between 2003 and 2006, a total of 12 patients were treated by SRT for uncontrolled acromegaly. Baseline clinical and demographic characteristics of all patients are shown in Table 1. The median age of patients was 50.5 years; 9 of 12 patients were female. All patients except \#7 and \#10 had previously undergone transsphenoidal surgery for pituitary GH producing adenoma, and had at least six months of medical therapy prior to SRT. Patients \#3 and \#5 were on dopamine agonist therapy alone whereas the remainder were on somatostatin analogue (SA) therapy. Prior to SRT, all but two patients had normal pituitary function (one with secondary hypogonadism and another with secondary hypothyroidism, both requiring replacement therapy). Stereotactic radiation therapy was tolerated without significant difficulty in all cases; no patient required a treatment break or interruption. The median follow-up following SRT was 28.5 months (range: $6-41$ months). No patients were lost to follow-up.

\section{Hormonal Profile}

Changes in GH and IGF-1 levels are presented in Table 2 and graphically in Figure 2. Median GH dropped from a basal value of $4.1 \mu \mathrm{g} / \mathrm{L}$ to $1.3 \mu \mathrm{g} / \mathrm{L}$ with a median reduction of $2.3 \mu \mathrm{g} / \mathrm{L}$ (p =

Table 2: Changes in GH and IGF-1 levels following SRT

\begin{tabular}{c|c|c|c|c|c}
\hline $\begin{array}{c}\text { Patient } \\
\#\end{array}$ & $\begin{array}{c}\text { Basal IGF-1 } \\
\text { (normal } \\
\text { range: } \boldsymbol{\mu g} / \mathbf{L})\end{array}$ & $\begin{array}{c}\text { Basal GH } \\
\text { (reference } \\
\text { range: }<\mathbf{1} \\
\boldsymbol{\mu g} / \mathbf{L})\end{array}$ & $\begin{array}{c}\text { Follow- } \\
\mathbf{u p} \\
(\mathbf{m o n t h s})\end{array}$ & $\begin{array}{c}\text { Recent } \\
\text { IGF-1 } \\
(\boldsymbol{\mu g} / \mathbf{L})\end{array}$ & $\begin{array}{c}\text { Recent } \\
\mathbf{G H} \\
(\boldsymbol{\mu g} / \mathbf{L})\end{array}$ \\
\hline 1 & $549(109-284)$ & 4.9 & 35 & 129 & 1.3 \\
\hline 2 & $486(101-277)$ & 2.2 & 34 & 174 & 1.2 \\
\hline 3 & $570(109-284)$ & 2.3 & 33 & 276 & 0.8 \\
\hline 4 & $1090(75-212)$ & 5.7 & 37 & 251 & 3.3 \\
\hline 5 & $670(87-238)$ & 5.1 & 41 & 239 & 2.2 \\
\hline 6 & $431(115-307)$ & 5.6 & 20 & 258 & 2.42 \\
\hline 7 & $814(115-307)$ & 8.8 & 34 & 371 & 1.4 \\
\hline 8 & $542(178-295)$ & 3.2 & 12 & 351 & 1.4 \\
\hline 9 & $431(87-238)$ & 2.3 & 8 & 263 & 0.73 \\
\hline 10 & $495(81-225)$ & 0.5 & 24 & 332 & 0.5 \\
\hline 11 & $486(87-238)$ & 14.2 & 6 & 241 & 0.73 \\
\hline 12 & $689(87-238)$ & 2.7 & 6 & 380 & 0.5 \\
\hline
\end{tabular}




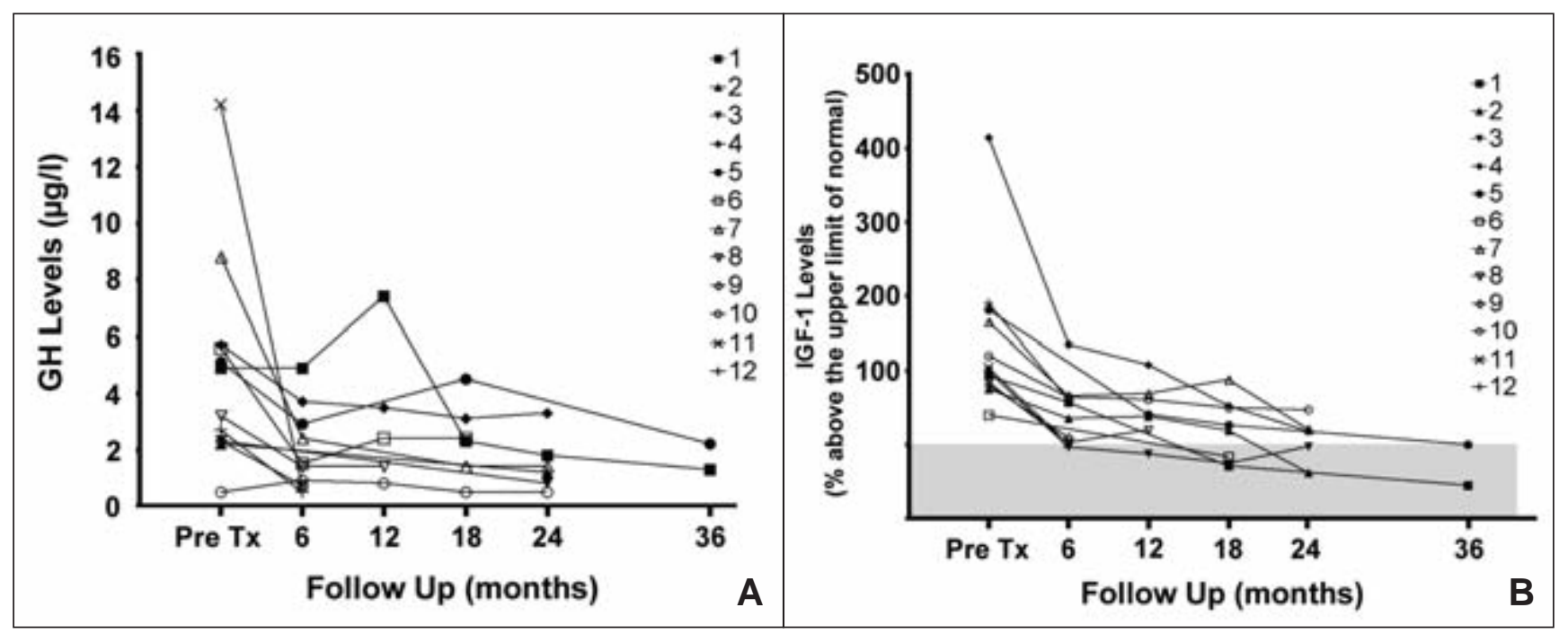

Figure 2: A: GH values pre-SRT and at each scheduled follow-up visit. B: IGF-1 values (percent above the upper limit of normal) pre-SRT and at each scheduled follow-up visit. The shaded area represents the normal range.

0.003). More importantly, all patients had marked reductions in their serum IGF-1, dropping by $47.8 \%$ from a median basal value of $545.5 \mu \mathrm{g} / \mathrm{L}$ to $260.5 \mu \mathrm{g} / \mathrm{L}(\mathrm{p}=0.002)$. At the time of the last evaluation, four patients (\#1, 2, 3 and 6) achieved bio-chemical remission while two other patients (\#5 and 11) achieved nearnormal IGF-1 levels. One patient (\#3) was able to discontinue his medical treatment while maintaining biochemical remission, whereas two patients (\#1 and 2) required smaller doses of SA therapy. Patient \#7 was started on pegvisomant six months after the completion of SRT due to persistent elevation of serum IGF1 despite maximum dose of SA therapy. With regards to pituitary function, Patient \#3 had secondary hypogonadism and Patient \#4 had secondary hypothyroidism prior to SRT. One patient (\#10) developed new secondary hypoadrenalism 24 months after SRT requiring hydrocortisone replacement therapy. There was no new abnormality in the pituitary function testing of other patients.

\section{Tumour Size}

The MRI images pre- and post-SRT treatment are shown in Figure 3 . The data regarding tumour volume are summarized in Table 3. The mean tumour volumes before and after SRT were $1.56 \mathrm{cc}$ and $0.96 \mathrm{cc}$, respectively. The mean tumour volume was reduced by $0.60 \mathrm{cc}(40 \%)(\mathrm{p}=0.005)$.

\section{Visual Field Testing}

No patient had a new visual field defect at most recent testing. Transient changes on Goldmann visual field testing were noted at six months in Patients \#4 and \#8, and at 24 months in Patient $\# 5$, most often consisting of a transient superior depression and not correlating with any detectable changes on MRI. In Patient $\# 1$, there was an unexplainable improvement in the pre-SRT visual field abnormality.

\section{DISCUSSION}

The criteria for remission in acromegaly patients have changed over the years. The currently employed criteria are based on consensus and include achieving basal GH of $<2.5$ $\mu \mathrm{g} / \mathrm{L}$, normal age-gender matched IGF-1, and GH suppressibility to $<1 \mu \mathrm{g} / \mathrm{L}$ after an oral glucose $\operatorname{load}^{6}$. Both microsurgical tumour resection and medical therapy are regarded as effective first line treatments. In experienced hands, patients with microadenomas can expect a cure rate of $>80 \%{ }^{7,8}$. However,

Table 3: Effect of SRT on tumour volumes and visual field tests

\begin{tabular}{c|c|c|c}
\hline $\begin{array}{c}\text { Patient } \\
\text { No. }\end{array}$ & $\begin{array}{c}\text { Pre-SRT } \\
\text { treatment } \\
\text { tumour volume } \\
\text { (cc) }\end{array}$ & $\begin{array}{c}\text { Post-SRT } \\
\text { treatment } \\
\text { tumour } \\
\text { volume (cc) }\end{array}$ & Visual field change \\
\hline 1 & 4.87 & 3.26 & $\begin{array}{c}\text { Improvement in pre-SRT } \\
\text { right eye superior } \\
\text { temporal scotoma }\end{array}$ \\
\hline 2 & 1.46 & 0.64 & No Change \\
\hline 3 & 1.65 & 0.54 & No Change \\
\hline 4 & 1.16 & 0.71 & $\begin{array}{c}\text { Transient superior wedge } \\
\text { in left eye at 6 months }\end{array}$ \\
\hline 5 & 1.22 & 0.30 & $\begin{array}{c}\text { Transient superior } \\
\text { temporal disturbance at } \\
24 \text { months }\end{array}$ \\
\hline 6 & 0.61 & 0.21 & No Change \\
\hline 7 & 1.17 & 1.93 & No Change \\
\hline 8 & 3.29 & 2.49 & $\begin{array}{c}\text { Transient superior } \\
\text { depression at } 6 \\
\text { months }\end{array}$ \\
\hline 9 & & & No Change \\
\hline 10 & 0.66 & 0.17 & No Change \\
\hline 11 & 0.22 & 0.21 & No Change \\
\hline 12 & 1.94 & 0.45 & No Change \\
\hline
\end{tabular}




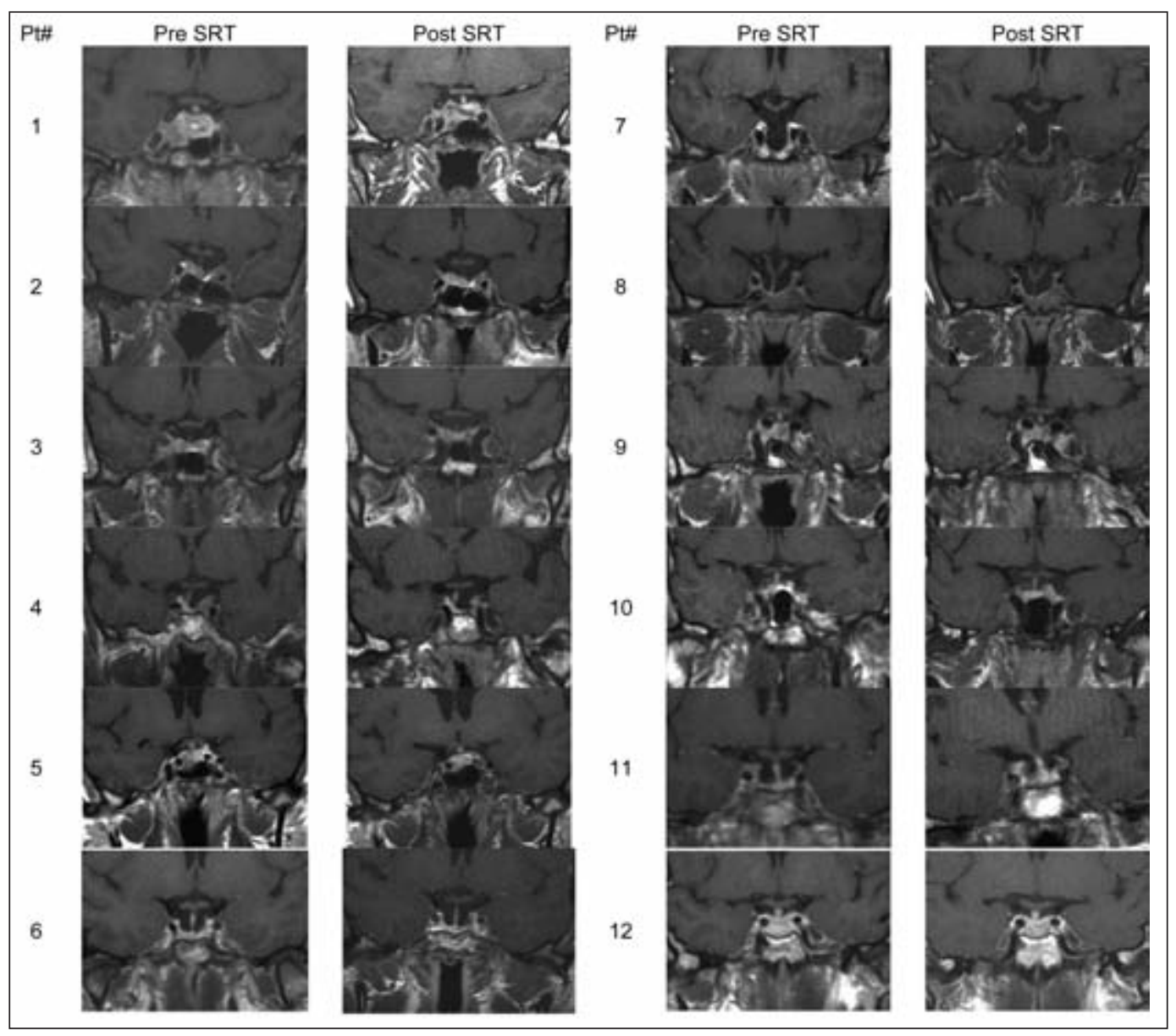

Figure 3: Coronal MRI (post-gadolinium) images at the level of the hypothalamic pituitary stalk, pre-SRT treatment and at last follow-up visit.

given the fact that over $70 \%$ patients with acromegaly have macroadenomas, the cure rate in this patient population with surgery alone is $<50 \%$. These surgically incurable cases have traditionally received further treatment with either pharmacologic or radiation therapy. The main disadvantages of pharmacologic therapy are the need for life-long treatment, high cost and the lack of effectiveness in biochemical and tumour control. Of the currently available choices, dopaminergic agonists (bromocriptine and cabergoline) have been reported to lower IGF-1 in 10-30\% ${ }^{10,11}$ whereas the SA (octreotide and lanreotide) may achieve biochemical control in $50-60 \%$ of cases $^{12}$. The recently available $\mathrm{GH}$ receptor antagonist, pegvisomant, achieves biochemical control in $90 \%$ of patients ${ }^{13}$ but is also the most expensive, lacks long-term safety data, and does not act to control tumour growth ${ }^{14}$.

The role of radiation in uncontrolled acromegaly has been controversial and reflects the development of modern radiation delivery techniques. While some studies have proposed a definite role for conventional radiotherapy $(\mathrm{RT})^{15,16}$, others have reported a lack of efficacy ${ }^{17,18}$. Conventional RT has also been linked to a high incidence of side effects such as hypopituitarism, cerebral tissue necrosis, neurophysiological impairment, damage to the optic pathways and even development of secondary tumours ${ }^{19-22}$. Although direct comparison with previously published studies is unfeasible because of outdated criteria for cure $^{23-26}$, the reported rate of normalization of IGF-1 after conventional RT using more stringent modern criteria is no higher than $60-70 \%$ at ten years ${ }^{16,27}$.

The success of SRS in treating patients with acromegaly, and employing current criteria for cure, has been variable with reported cure rates ranging from $43 \%-82 \%{ }^{28,29}$. In those patients where IGF-1 values have normalized, the mean time to IGF-1 normalization has been reported as two years ${ }^{30}$. Another recent study, where patients were tested with SRS despite the article's title suggesting treatment by SRT, reported remission rates of $30.5 \%$ at three years and $52.6 \%$ at five years ${ }^{3}$.

The role of SRT in the management of pituitary adenomas has recently been reported in another study ${ }^{31}$; however, only two of the reported 14 patients had GH-producing adenomas. In our study, $50 \%$ of patients achieved normal or near-normal IGF-1 over a median duration of 28.5 months (range $8-41$ months), early results that compare favourably with SRS. Furthermore, 
seven of eight patients with pre-treatment basal GH $>2.5 \mathrm{ug} / \mathrm{L}$ achieved target basal GH. One patient discontinued, while another two were able to reduce, the dosage of their SA therapy. During the SRT treatment, most of our patients (10 of 12) were maintained on SA therapy. Although it has been suggested by some that SA therapy may confer a radioprotective effect, thereby reducing the efficacy of radiation therapy ${ }^{32,33}$, others have not found such an effect ${ }^{3,15,34}$. In our study, both patients who were not on SA therapy achieved normal IGF-1, whereas four of ten who were on SA therapy achieved biochemical remission. Due to the limited sample size, we were unable to compare the two groups.

The proposed benefit of modern radiotherapy delivery systems, including SRT, over conventional RT is relative radiation sparing of the adjacent tissue. Consistent with this, no patient in our series reported any enduring symptoms or signs suggestive of local neurologic injury. One patient developed an additional pituitary hormone abnormality (secondary hypoadrenalism) at 24 months; longer term follow-up may see this incidence increase. New visual field abnormalities, defined strictly as any change found in Goldman visual field testing were observed in three patients. All of these new visual fields abnormalities were subclinical and resolved spontaneously without treatment. Furthermore, the defects were not consistently in the part of the visual field most likely to be affected by the radiation treatment, indicating that these new visual field abnormalities may simply reflect test-to-test variation. However, despite these encouraging early data, longer follow-up of these patients is required to determine the continuing safety of SRT and its effect on pituitary function and vision.

The current study is the first to report the outcome of a series of acromegaly patients treated with SRT. Our early results indicate that $50 \%$ of these patients will achieve biochemical remission, with or without the need for concomitant pharmacologic therapy, at 28.5 months. It remains to be seen whether longer follow-up of these patients will result in larger numbers of cures and larger numbers of patients being able to reduce or discontinue SA therapy. Although the primary treatment of acromegaly remains surgical, these results indicate that in carefully selected patients SRT is a treatment modality that should be considered in managing patients with uncontrolled acromegaly.

\section{ACKNOWLEDGEMENTS}

The authors thank Linda Clarke, Carla Roberts, Lorraine Smith and Lisa Tramble for their assistance in the preparation of this manuscript.

\section{REFERENCES}

1. Gramegna A. Revue neurologique. 1909; (17):15-7.

2. Landolt AM, Haller D, Lomax N, Scheib S, Schubiger O, Siegfried $\mathrm{J}$, et al. Stereotactic radiosurgery for recurrent surgically treated acromegaly: comparison with fractionated radiotherapy. J Neurosurg. 1998 Jun; 88(6): 1002-8.

3. Losa M, Gioia L, Picozzi P, Franzin A, Valle M, Giovanelli M, et al. The role of stereotactic radiotherapy in patients with growth hormone-secreting pituitary adenoma. J Clin Endocrinol Metab. $2008 \mathrm{Jul}$; 93(7): 2546-52.

4. Vik-Mo EO, Oksnes M, Pedersen PH, Wentzel-Larsen T, Rodahl E, Thorsen F, et al. Gamma knife stereotactic radiosurgery for acromegaly. Eur J Endocrinol. 2007 Sep; 157(3): 255-63.

5. Robar JL, Clark BG, Schella JW, Kim CS. Analysis of patient repositioning accuracy in precision radiation therapy using automated image fusion. J Appl Clin Med Phys. 2005; 6(1): 71-83.

6. Giustina A, Barkan A, Casanueva FF, Cavagnini F, Frohman L, Ho $\mathrm{K}$, et al. Criteria for cure of acromegaly: a consensus statement. J Clin Endocrinol Metab. 2000 Feb; 85(2): 526-9.

7. Gittoes NJ, Sheppard MC, Johnson AP, Stewart PM. Outcome of surgery for acromegaly--the experience of a dedicated pituitary surgeon. Q J Med. 1999 Dec; 92(12): 741-5.

8. Shimon I, Cohen ZR, Ram Z, Hadani M. Transsphenoidal surgery for acromegaly: endocrinological follow-up of 98 patients. Neurosurgery. 2001 Jun; 48(6): 1239-43.

9. Melmed S. Medical progress: acromegaly. N Engl J Med. 2006 Dec 14; 355(24): 2558-73.

10. Jaffe CA, Barkan AL. Treatment of acromegaly with dopamine agonists. Endocrinol Metab Clin North Am. 1992 Sep; 21(3): 713-35.

11. Jackson SN, Fowler J, Howlett TA. Cabergoline treatment of acromegaly: a preliminary dose finding study. Clin Endocrinol (Oxf). 1997 Jun; 46(6): 745-9.

12. Freda PU. Somatostatin analogs in acromegaly. J Clin Endocrinol Metab. 2002 Jul; 87(7): 3013-8.

13. Trainer PJ, Drake WM, Katznelson L, Freda PU, Herman-Bonert V, van der Lely AJ, et al. Treatment of acromegaly with the growth hormone-receptor antagonist pegvisomant. N Engl J Med. 2000 Apr 20; 342(16): 1171-7.

14. van der Lely AJ, Hutson RK, Trainer PJ, Besser GM, Barkan AL, Katznelson L, et al. Long-term treatment of acromegaly with pegvisomant, a growth hormone receptor antagonist. Lancet. 2001 Nov 24; 358(9295): 1754-9.

15. Castinetti F, Taieb D, Kuhn JM, Chanson P, Tamura M, Jaquet P, et al. Outcome of gamma knife radiosurgery in 82 patients with acromegaly: correlation with initial hypersecretion. J Clin Endocrinol Metab. 2005 Aug; 90(8): 4483-8.

16. Jenkins PJ, Bates P, Carson MN, Stewart PM, Wass JA. Conventional pituitary irradiation is effective in lowering serum growth hormone and insulin-like growth factor-I in patients with acromegaly. J Clin Endocrinol Metab. 2006 Apr; 91(4): 1239-45.

17. Barkan AL, Halasz I, Dornfeld KJ, Jaffe CA, Friberg RD, Chandler WF, et al. Pituitary irradiation is ineffective in normalizing plasma insulin-like growth factor I in patients with acromegaly. J Clin Endocrinol Metab. 1997 Oct; 82(10): 3187-91.

18. Cozzi R, Barausse M, Asnaghi D, Dallabonzana D, Lodrini S, Attanasio R. Failure of radiotherapy in acromegaly. Eur $\mathrm{J}$ Endocrinol. 2001 Dec; 145(6): 717-26.

19. Brada M, Ford D, Ashley S, Bliss JM, Crowley S, Mason M, et al. Risk of second brain tumour after conservative surgery and radiotherapy for pituitary adenoma. Br Med J. 1992 May 23; 304 (6838): 1343-6.

20. Simmons NE, Laws ER, Jr. Glioma occurrence after sellar irradiation: case report and review. Neurosurgery. 1998 Jan; 42 (1): $172-8$

21. Wass JA. Evidence for the effectiveness of radiotherapy in the treatment of acromegaly. J Endocrinol. 1997 Oct; 155 Suppl 1: S57-8.

22. Plowman PN. Pituitary adenoma radiotherapy-when, who and how? Clin Endocrinol (Oxf). 1999 Sep; 51(3): 265-71.

23. Pollock BE, Kondziolka D, Lunsford LD, Flickinger JC. Stereotactic radiosurgery for pituitary adenomas: imaging, visual and endocrine results. Acta Neurochir Suppl. 1994; 62: 33-8.

24. Hayashi M, Izawa M, Hiyama H, Nakamura S, Atsuchi S, Sato H, et al. Gamma Knife radiosurgery for pituitary adenomas. Stereotact Funct Neurosurg. 1999; 72 Suppl 1: 111-8.

25. Zhang N, Pan L, Wang EM, Dai JZ, Wang BJ, Cai PW. Radiosurgery for growth hormone-producing pituitary 
adenomas. J Neurosurg. 2000 Dec; 93 Suppl 3: 6-9.

26. Jezkova J, Marek J, Hana V, Krsek M, Weiss V, Vladyka V, et al. Gamma knife radiosurgery for acromegaly--long-term experience. Clin Endocrinol (Oxf). 2006 May; 64(5): 588-95.

27. Powell JS, Wardlaw SL, Post KD, Freda PU. Outcome of radiotherapy for acromegaly using normalization of insulin-like growth factor I to define cure. J Clin Endocrinol Metab. 2000 May; 85(5): 2068-71.

28. Jackson IM, Noren G. Role of gamma knife therapy in the management of pituitary tumors. Endocrinol Metab Clin North Am. 1999 Mar; 28(1): 133-42.

29. Ikeda H, Jokura H, Yoshimoto T. Transsphenoidal surgery and adjuvant gamma knife treatment for growth hormone-secreting pituitary adenoma. J Neurosurg. 2001 Aug; 95 (2): 285-91.

30. Attanasio R, Baldelli R, Pivonello R, Grottoli S, Bocca L, Gasco V, et al. Lanreotide $60 \mathrm{mg}$, a new long-acting formulation: effectiveness in the chronic treatment of acromegaly. J Clin Endocrinol Metab. 2003 Nov; 88(11): 5258-65.
31. McClelland S, III, Higgins PD, Gerbi BJ, Orner JB, Hall WA. Fractionated stereotactic radiotherapy for pituitary adenomas following microsurgical resection: safety and efficacy. Technol Cancer Res Treat. 2007 Jun; 6(3): 177-80.

32. Landolt AM, Lomax N, Scheib SG, Wellis G. Endocrine results of gamma knife radiosurgery in acromegaly and prolactinomas. In: Kondziolka D, editor. Radiosurgery. Basel: 2002. p. 87-92.

33. Pollock BE, Jacob JT, Brown PD, Nippoldt TB. Radiosurgery of growth hormone-producing pituitary adenomas: factors associated with biochemical remission. J Neurosurg. 2007 May; 106(5): 833-8.

34. Attanasio R, Epaminonda P, Motti E, Giugni E, Ventrella L, Cozzi $\mathrm{R}$, et al. Gamma-knife radiosurgery in acromegaly: a 4-year follow-up study. J Clin Endocrinol Metab. 2003 Jul; 88(7): 3105-12. 